\title{
Reactivity of electrophilic $\mathrm{Cp} * \mathrm{Ru}(\mathrm{NO})$ complex towards alcohols
}

Jason Diaz ${ }^{1}$, Kellee Rich ${ }^{1}$, Semeret Munie ${ }^{1}$, Christopher R. Zoch ${ }^{2}$, John L. Hubbard ${ }^{2}$, Anna S. Larsen $^{1 *}$

Department of Chemistry, Ithaca College, Ithaca, NY (1);

Department of Chemistry and Biochemistry, Utah State University, Logan, UT (2)

*alarsen@ithaca.edu

\begin{abstract}
Treatment of the complex $1 \mathrm{Cp} * \mathrm{Ru}(\mathrm{NO})(\mathrm{OTf})_{2} \quad\left(\mathrm{OTf}=\mathrm{OSO}_{2} \mathrm{CF}_{3}, \mathrm{Cp}^{*}=\eta^{5}-\right.$ $\left.\mathrm{C}\left(\mathrm{CH}_{3}\right)_{5}\right)$ with neat 2-propanol results in the rapid quantitative formation of the $\mathrm{Ru}(0)$ complex $[\mathrm{Cp} * \mathrm{Ru}(\mu-\mathrm{NO})]_{2}$ and $\left(\mathrm{CH}_{3}\right)_{2} \mathrm{C}=\mathrm{O}$. Formation of $\mathrm{H}_{2}$ and $\mathrm{CHDCl}_{2}$ is detected when the reaction between 1 and 2-propanol occurs in $\mathrm{CDCl}_{3}$, indicating possible formation of a short-lived metal hydride species. Similar results are observed upon treatment of 1 with ethanol and methanol, with formation of acetaldehyde and formaldehyde, respectively. The kinetics of the oxidation of 2-propanol by complex 1 is studied by ${ }^{1} \mathrm{H}$ NMR spectroscopy in $\mathrm{CH}_{2} \mathrm{Cl}_{2}$ at variable temperatures and the reaction is found to be first-order in complex $\mathbf{1}$ and in 2-propanol. The kinetic isotope effect for the reaction of 1 with $\left(\mathrm{CD}_{3}\right)_{2} \mathrm{CD}-\mathrm{OD}$ at $-11^{\circ} \mathrm{C}$ is determined to be $k_{\mathbf{H}} / k_{\mathbf{D}}=2.0$ (3). A mechanism for alcohol oxidation by electrophilic ruthenium (II) complexes via a $\beta$-hydrogen elimination step is proposed. The pre-equilibrium exchange step between complex $\mathrm{Cp} * \mathrm{Ru}(\mathrm{NO})(\mathrm{OTf})_{2}(\mathbf{1})$ and alcohol-coordinated species is examined by ${ }^{19} \mathrm{~F}$ and ${ }^{1} \mathrm{H}$ NMR spectroscopy in $\mathrm{CH}_{2} \mathrm{Cl}_{2}$ solution, where triflate substitution is found to be exothermic and entropically unfavorable. The synthesis and solid state structure of the chelate-stabilized complex diol salt $\left[\mathrm{Cp} * \mathrm{Ru}(\mathrm{NO})\left(\mathrm{HO}-\mathrm{CH}_{2} \mathrm{CH}_{2}-\mathrm{OH}\right)\right][2 \mathrm{OTf}]$ are discussed.
\end{abstract}




\section{Introduction}

The catalytic transformation of functional groups in organic molecules is a major target of research in modern organometallic chemistry [1]. A transition-metal complex reactivity can be tuned both electronically and sterically, by varying the metal and/or ligands. Often, due to limited understanding of the underlying trends in such reactions, success in transition-metal catalysis depends largely on serendipity. Therefore, mechanistic studies of pro-catalytic reactions of transition-metal complexes contribute towards developing efficient catalytic systems [2]. Among these, oxidation of alcohols into aldehydes and ketones is a catalytic transformation of particular interest, due to commercial, medical and agricultural applications $[3,4]$.

There are multiple reported examples of transition-metal complex mediated oxidation of alcohols [5]. Efficient procedures are developed for the oxidation of a wide variety of alcohol functionalities by complexes of ruthenium, copper osmium, palladium, rhodium, cobalt and iridium [6]. In view of the development of reversible dehydrogenation-hydrogenation catalytic cycles for energy storage applications, atom efficient acceptorless alcohol dehydrogenation has recently attracted special attention [7].

Although extensive mechanistic studies have been conducted on $\beta$-hydrogen elimination from metal alkyl complexes [8], $\beta$-hydrogen elimination from alcohol and alkoxo complexes is less understood and is more complicated for the cases where heteroatom functionalities are present in the $\beta$-carbon position $[9,10,11,12]$. Triflate ( $\mathrm{OTf}, \mathrm{OSO}_{2} \mathrm{CF}_{3}$ ) complexes have been shown to possess remarkable catalytic and stoichiometric reactivity over a range of reaction conditions [13]. Among the important features of the ruthenium triflate system under consideration are the aqueous solubility and electrophilicity, resulting in water 
binding and activation by the cationic $[\mathrm{Cp} * \mathrm{Ru}(\mathrm{NO})]^{2+}$ fragment $\left(\left(\mathrm{Cp}^{*}=\eta^{5}-\mathrm{C}\left(\mathrm{CH}_{3}\right)_{5}\right)[14]\right.$. The present study deals with the reactivity of the $\mathrm{Cp} * \mathrm{Ru}(\mathrm{NO})(\mathrm{OTf})_{2}$ complex with alcohols, probing the thermodynamics of the triflate-alcohol coordination exchange and the kinetic aspects of the subsequent stoichiometric oxidation of alcohol.

\section{Results and Discussion:}

\subsection{Redox reactivity of $C p^{*} \mathrm{Ru}(\mathrm{NO})(\mathrm{OTf})_{2}$ towards alcohols}

NMR studies in the Hubbard group showed that the ruthenium di-triflate complex 1, in dichloromethane solution, reacts with excess 2-propanol to form acetone [15]. Subsequently, it was discovered that addition of $\mathrm{Cp}^{*} \mathrm{Ru}(\mathrm{NO}) \mathrm{OTf}_{2}$ to neat 2-propanol results in rapid precipitation of the bright red $\mathrm{Ru}=\mathrm{Ru}$ double bond product $\mathbf{2}$ in the form of an analytically pure red solid (Eq. 1).

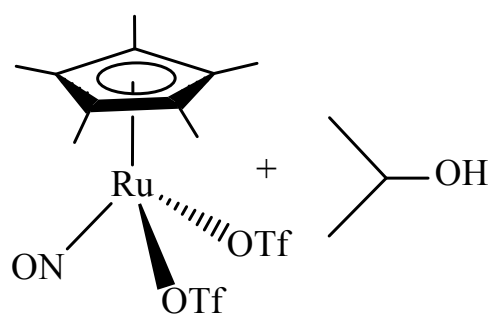

1

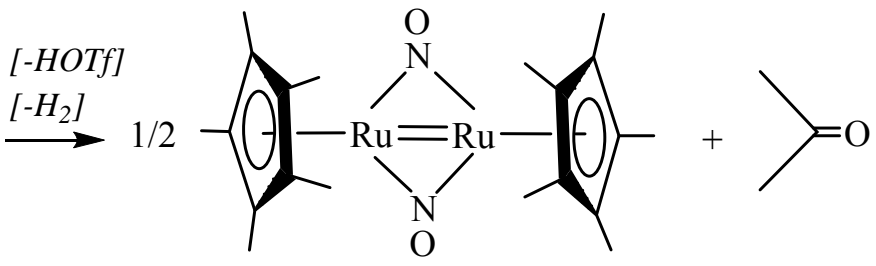

$$
\mathrm{OTf}=\mathrm{OSO}_{2} \mathrm{CF}_{3}
$$

Initial identification of $[\mathrm{Cp} * \mathrm{Ru}(\mu-\mathrm{NO})]_{2} \mathbf{2}$ as the main product of the reaction was obscured in the dilute $\mathrm{CH}_{2} \mathrm{Cl}_{2}$ or $\mathrm{CDCl}_{3}$ solutions of $\mathbf{1}$, upon addition of alcohols at ambient temperature, due to the activation of $[\mathrm{Cp} * \mathrm{Ru}(\mu-\mathrm{NO})]_{2}$ towards the chloride abstraction from the solvent. The formation of ruthenium(I) and ruthenium(II) chloride complexes occurs, 
eventually converting completely to green $\mathrm{Cp}^{*} \mathrm{Ru}(\mathrm{NO}) \mathrm{Cl}_{2}$. Due to these processes, at ambient temperatures, after the reaction of 1 with 2-propanol in $\mathrm{CH}_{2} \mathrm{Cl}_{2}$ is complete, the red color of the solution darkens within 5 minutes. The ${ }^{1} \mathrm{H}$ NMR spectrum demonstrates a decrease of the $\mathrm{Cp}^{*}$ proton resonance intensity of 2 at $\delta 1.65$, while a new signal at $\delta 1.83$, for the $\mathrm{Cp} *$ resonance of $\mathrm{Cp} * \mathrm{Ru}(\mathrm{NO}) \mathrm{Cl}_{2}$, appears simultaneously.

The first synthesis of complex 2 was reported in 1987 by the Bergman group, via reduction of $\mathrm{Cp}^{*} \mathrm{Ru}(\mathrm{NO}) \mathrm{Cl}_{2}$ with excess $\mathrm{Zn}$ dust in dry ethanolic solutions [16a]. This synthetic procedure can be challenging due to the highly reactive nature of complex 2 [16b]. More facile access to complex 2 via Eq.(1) allowed us to obtain X-ray quality crystals and determine the $\mathrm{Ru}=\mathrm{Ru}$ double bond distance, some twenty years after the compound was first reported [17].

The redox reaction of $\mathbf{1}$ also occurs with an excess of methanol or ethanol, leading to the formation of the corresponding aldehydes, as confirmed by ${ }^{1} \mathrm{H}$ and ${ }^{13} \mathrm{C}$ NMR spectroscopy in $\mathrm{CDCl}_{3}$. No reactivity is observed between complex 1 and $t$-butanol. The difficulty of binding to the metal center can be explained by steric hindrance in this ligand. The reaction between $\mathbf{1}$ and alcohols proceeds in the presence of water; in a 50-50 ethanol-water mixture the reduction of $\mathbf{1}$ occurs readily and $[\mathrm{Cp} * \mathrm{Ru}(\mu-\mathrm{NO})]_{2}(2)$ precipitates from the solution. When the same reaction occurs in pure ethanol, product 2 remains in solution.

In the reaction with ethanol in $\mathrm{CH}_{2} \mathrm{Cl}_{2}$, acetaldehyde and acetal formation is detected in the ${ }^{1} \mathrm{H}$ NMR spectrum. In experiments performed with $\mathrm{CH}_{3} \mathrm{C}^{13} \mathrm{H}_{2} \mathrm{OH}$ in $\mathrm{CDCl}_{3}$ the signals at $\delta$ 99.48 and 60.68 indicate formation of acetal $\mathrm{CH}_{3}{ }^{13} \mathrm{CH}\left(\mathrm{O}^{13} \mathrm{CH}_{2} \mathrm{CH}_{3}\right)_{2}$ [18]. In the studies with ${ }^{13} \mathrm{C}$-labeled $\mathrm{MeOH}$, characteristic signals of dimethoxymethane, the product of the reaction between formaldehyde and methanol, are observed in the ${ }^{13} \mathrm{C} \mathrm{NMR}$ spectrum in $\mathrm{CDCl}_{3}$ at $\delta$ 97.50 and 55.04. An unidentified intermediate with the $\mathrm{Cp}^{*}$ proton resonance at $\delta 1.78$ is 
observed in the reaction with methanol, which converts to the dimeric $[\mathrm{Cp} * \mathrm{Ru}(\mu-\mathrm{NO})]_{2}$ complex 2, within 30 minutes, at ambient temperature. Attempts to isolate and further characterize this intermediate have been unsuccessful.

In dichloromehane solution at low alcohol concentrations (with $<2$ equiv of alcohol per initial amount of $\mathbf{1}$ present) only coordination of alcohol at the ruthenium center is observed, without a redox process taking place. We will first discuss ligand exchange equilibrium between complex 1 and coordinated alcohol species, and then proceed to the discussion of the alcohol oxidation/ ruthenium reduction mechanistic studies.

\subsection{Substitution of coordinated OTf - by alcohols.}

X-ray diffraction studies show that the triflate ligands in complex $\mathbf{1}\left(\mathrm{Cp} * \mathrm{Ru}(\mathrm{NO}) \mathrm{OTf}_{2}\right)$ are bound tightly to the $[\mathrm{Cp} * \mathrm{Ru}(\mathrm{NO})]^{2+}$ fragment [14]. However, in dichloromethane solution, the triflate ligands of complex 1 undergo reversible substitution by simple alcohols detectable by NMR spectroscopy [15]. The two-step substitution equilibrium can be, in general form, described by Eq. (2) below (where $[\mathrm{Ru}]$ stands for $[\mathrm{Cp} * \mathrm{Ru}(\mathrm{NO})]$ fragment):

$$
\begin{aligned}
& {[\mathrm{Ru}](\mathrm{OTf})_{2}+\mathrm{ROH} \stackrel{\mathrm{K}_{\mathrm{eq} 1}}{\rightleftharpoons}[\mathrm{Ru}](\mathrm{OTf})(\mathrm{ROH})^{+}+\mathrm{OTf}^{-}} \\
& {[\mathrm{Ru}](\mathrm{OTf})(\mathrm{ROH})^{+}+\mathrm{ROH} \stackrel{\mathrm{K}_{\mathrm{eq} 2}}{\rightleftharpoons}[\mathrm{Ru}](\mathrm{ROH})_{2}{ }^{2+}+\mathrm{OTf}^{-}}
\end{aligned}
$$

Evidence for the alcohol-bound species is found in the ${ }^{1} \mathrm{H}$ NMR spectra of 1 in dichloromethane with $<2$ equivalents of alcohol, where the $\mathrm{Cp}^{*}$ resonances of complex 1 and its mono- and disubstituted alcohol derivatives appear between $\delta 1.87$ and 1.89 (see Figure 1, also showing an inset with the temperature dependence). The diastereotopic $\beta$-hydrogen signals for the bound $\mathrm{CH}_{3} \underline{\mathrm{C}}_{2} \mathrm{OH}$ are observable downfield from the free alcohol methylene proton signals. 


\section{--INSERT FIG. 1}

The triflate group binding and dissociation in these complexes can be monitored by ${ }^{19} \mathrm{~F}$ NMR spectroscopy [14, 20]. Fig. 2 shows the ${ }^{19}$ F NMR spectra of complex 1 solution, with 2 equivalents of ethanol, where complex 1 remains the major species, with triflate dissociation becoming more favorable at lower temperatures. The mass conservation considerations can be applied to estimate the equilibrium concentration of each species in Eq. 2, including the ${ }^{19} \mathrm{~F}$ NMR silent di-alcohol bound product of step 2, at variable temperatures [14].

All the spectra for the thermodynamic analysis were collected in the presence of the nonreactive internal standard, 3,5-bis(trifluoromethyl)benzene. The estimated thermodynamic values were based on Eq.(2) stoichiometry for $\Delta \mathrm{H}_{1}(\mathrm{kcal} / \mathrm{mol}), \Delta \mathrm{S}_{1}(\mathrm{eu}), \Delta \mathrm{H}_{2}(\mathrm{kcal} / \mathrm{mol}), \Delta \mathrm{S}_{2}$ (eu): -2.5 (2), -20 (10), -2.0 (5), -16 (9) for methanol; -15 (1), -40 (20), -13 (1), -40 (30) for ethanol and -10 (1), -40 (20), -6.5 (5), -30 (10) for 2-propanol substitutions, respectively (carried out for 0.02-0.03 M solutions of 1 in dichloromethane in the presence of 1.5-2 equiv of alcohols). The absolute values are not very reliable in this case, due to expected ion-pairing behavior for this system that is not accounted for in this analysis. Equilibrium studies for the diol complex $\mathbf{3}$ (Eq.3), including those in the presence of excess triflate, confirm the propensity of this system for ion pairing. Ion pairing is more pronounced in these conditions, due to the relatively low polarity of dichloromethane. No ion pairing was observed in the related $\mathrm{Cp}^{*} \mathrm{Ru}(\mathrm{NO}) \mathrm{CH}_{3} \mathrm{OTf}$ system, where the investigation of the triflate substitution was carried out in more polar THF solutions $[19,20]$.

The analysis demonstrates that release of triflate is an exothermic process, with negative $\Delta \mathrm{S}$ values most likely due to the required reorganization of the solvent around newly formed 
ionic particles; similar to the displacement of $\mathrm{OTf}^{-}$in $\mathbf{1}$ by $\mathrm{H}_{2} \mathrm{O}$ ligands in $\mathrm{CH}_{2} \mathrm{Cl}_{2}$, where the negative $\Delta S$ values reflect the need for solvent reorganization around formed ion pairs [20, 14].

\section{---INSERT FIG. 2}

Attempts to isolate alcohol-coordinated complexes have been unsuccessful, as these salts do not precipitate from $\mathrm{CH}_{2} \mathrm{Cl}_{2} /$ hexane mixtures at $-78{ }^{\circ} \mathrm{C}$ and solvent removal in vacuo results in recovery of 1 . Alkoxide complexes are not observed in these alcohol binding reactions, and attempts to remove protons by addition of strong base in this system generally lead to decomposition of the complexes [21]. The alcohol-coordinated product can be stabilized by the chelating effect of bidentate diol ligands.

\subsection{Synthesis and characterization of [Cp*Ru(NO)(HO-CH $\left.\left.\mathrm{CH}_{2} \mathrm{CH}_{2}-\mathrm{OH}\right)\right][\mathrm{OTf}]_{2}(3)$}

Treatment of a $\mathrm{CHCl}_{3}$ solution of complex 1 with 3 equivalents of $\mathrm{HO}-\mathrm{CH}_{2} \mathrm{CH}_{2}-\mathrm{OH}$ results in rapid color change from purple to red and precipitation of the $[\mathrm{Cp} * \mathrm{Ru}(\mathrm{NO})(\mathrm{HO}-$ $\left.\left.\mathrm{CH}_{2} \mathrm{CH}_{2}-\mathrm{OH}\right)\right]\left[\mathrm{OTf}_{2}\right]$ (3) as dark red-orange crystals (Eq. 3) [15b]. The ${ }^{1} \mathrm{H}$ NMR spectrum of complex 2 in $\mathrm{CH}_{2} \mathrm{Cl}_{2}$ shows a $\mathrm{Cp}^{*}$ resonance at $\delta 1.93$, two broad resonances of the diastereotopic methylene pairs of protons at $\delta 4.23$ and 3.35, and a hydroxyl proton signal at $\delta$ 11.13.

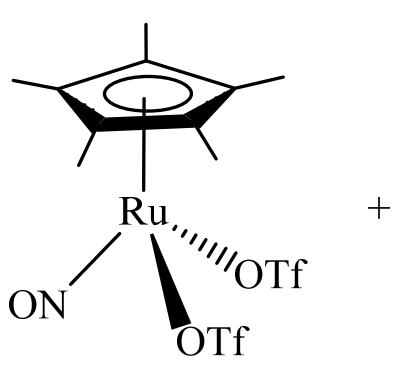

1

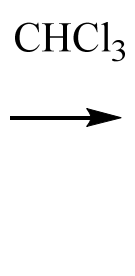

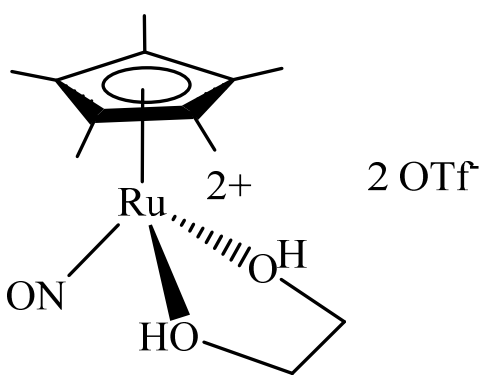

3 
The structure of the complex salt $\mathbf{3}$ has been determined by single crystal X-ray diffraction [22]. The cationic structure of $\mathbf{3}$ consists of a three-legged "piano-stool" with two "legs" joined by the ethylene fragment of the $\mathrm{HO}-\mathrm{CH}_{2} \mathrm{CH}_{2}-\mathrm{OH}$ molecule (Fig. 3).

\section{-INSERT FIGURE 3}

The ethylene glycol ligand forms a non-planar metallacyclic ring by chelating to the ruthenium atom. The non-bonded $\mathrm{O}(3)-\mathrm{O}(7)$ and $\mathrm{O}(2)-\mathrm{O}(5)$ distances of 2.55 and $2.57 \AA$ are indicative of intramolecular hydrogen bonding between ethylene glycol and triflate ligands [23]. In response to the involvement of $\mathrm{O}(5)$ and $\mathrm{O}(7)$ in these interactions, the corresponding $\mathrm{S}(1)-\mathrm{O}(7)$ and $\mathrm{S}(2)-\mathrm{O}(5)$ bonds are elongated compared to other $\mathrm{S}-\mathrm{O}$ bonds in the triflate fragments. The $\angle$ $\mathrm{Ru}-\mathrm{N}-\mathrm{O}$ is $159.45^{\circ}$, indicating significant $\pi$-donation from the oxygen atoms of ethylene glycol, resulting in the deviation from linear coordination of nitrosyl [24]. This value is very close to the $159.6^{\circ} \angle \mathrm{Ru}-\mathrm{N}-\mathrm{O}$ reported for complex 1 [14]. The solid state structure does not show the bonding angle $\angle \mathrm{Ru}-\mathrm{N}-\mathrm{O}$ to be particularly sensitive to the changing electronic environment at the metal center, which could be expected from switching two bound triflates for a more electron-donating diol ligand. However, there is a clear difference in the frequency of the nitrosyl IR stretches of complexes $\mathbf{1}$ and $\mathbf{3}$ in solution: upon addition of excess of ethylene glycol to the $\mathrm{CH}_{2} \mathrm{Cl}_{2}$ solution of 1 the observed $v_{\mathrm{NO}}$ value in the IR spectrum shifts from 1850 $\mathrm{cm}^{-1}$ to $1790 \mathrm{~cm}^{-1}$, due to formation of the diol-coordinated complex 3 . The $v_{\mathrm{NO}}$ value in these complexes is expected to be affected by back-bonding from ruthenium, which depends on electron donation from other ligands. Thus, the lower $v_{\mathrm{NO}}$ value in $\mathbf{3}$ can be explained by coordination of the more electron-donating diol ligand.

Dissociation of ethylene glycol from complex $\mathbf{3}$, with formation of minor equilibrium amounts of starting complex $\mathbf{1}$, occurs in $\mathrm{CH}_{2} \mathrm{Cl}_{2}$ solutions of 3 (Eq. 4). The regeneration of small amounts of $\mathbf{1}$ is evident from the presence of a $\mathrm{Cp}^{*}$ resonance at $\delta 1.89$ in the ${ }^{1} \mathrm{H}$ NMR spectrum and a resonance at $\delta-77.0$ in ${ }^{19} \mathrm{~F}$ NMR spectrum, corresponding to the bound OTf. 
Since the process in Eq. (4) leads to elimination of the ions and formation of the neutral molecules, it is entropically favorable and is characterized by positive $\Delta \mathrm{S}$ value, estimated from the ${ }^{19} \mathrm{~F}$ NMR spectra analysis [21].

$\left[\mathrm{Cp} * \mathrm{Ru}(\mathrm{NO})\left(\mathrm{HO}-\mathrm{CH}_{2} \mathrm{CH}_{2}-\mathrm{OH}\right)\right]^{2+}+2 \mathrm{OTf}^{-} \rightleftharpoons 1+\mathrm{HO}^{-} \mathrm{CH}_{2} \mathrm{CH}_{2}-\mathrm{OH}$

The open-ring intermediate where the ethylene glycol ligand is mono-bound to the ruthenium center was not observed by IR spectroscopy methods. It is also notable that no redox reaction occurs upon addition of a large excess of ethylene glycol to complex $\mathbf{1}$ or $\mathbf{3}$, presumably due to the strong stabilizing effect of the chelated diol ligand.

\subsection{Mechanistic studies of alcohol oxidation by complex 1.}

A series of kinetics studies have been undertaken to gain mechanistic insight into the redox process between excess alcohol and complex 1 . The reaction of complex 1 $\left(\mathrm{Cp} * \mathrm{Ru}(\mathrm{NO}) \mathrm{OTf}_{2}\right)$ with 2-propanol yielding $[\mathrm{Cp} * \mathrm{Ru}(\mu-\mathrm{NO})]_{2}$ and an equimolar amount of acetone is instantaneous in the neat 2-propanol. In dichloromethane solutions this redox process is quite facile, but allows for kinetic studies by ${ }^{1} \mathrm{H}$ NMR methods at low temperatures. NMR spectra of the reaction mixture show the appearance of the characteristic $\mathrm{Cp}^{*}$ resonance of 2 at $\delta 1.65$ with a corresponding decrease in the intensity of the $\mathrm{Cp}^{*}$ resonance of complex 1 between $\delta 1.87$ and1.89.

Kinetics of the oxidation reaction of 1 in the presence of ca. 100 equivalents of 2propanol was monitored via the disappearance of the $\mathrm{Ru}(\mathrm{II})$ species' $\mathrm{Cp}^{*}$ signal. The amount of $\mathrm{Ru}(\mathrm{II})$ complexes in solution was estimated as a total integral of the $\mathrm{Cp} *$ signal between $\delta 1.87$ and 1.89 (area shown on Fig. 1(B)), corresponding to the complex 1 together with its alcohol substituted derivatives. Table 1 summarizes observed rate constant values determined for the reaction of 1 with 2-propanol at varied concentrations of complex 1 and 2-propanol in the temperature range between -47 and $-11^{\circ} \mathrm{C}$. Analysis of the concentration-time profiles for the 
disappearance of the $\mathrm{Ru}(\mathrm{II})$ species shows that the reaction is first order in 1( Fig.4A) [25]. Therefore, the coupling of two $\mathrm{Cp} * \mathrm{Ru}(\mathrm{NO})$ fragments to form the dinuclear $\mathrm{Ru}=\mathrm{Ru}$ product 2 cannot be the rate determining step (RDS) for the overall reaction. Fig. 4B shows the Eyring plot used to determine the activation parameters for the reaction. Fig. 5 shows a logarithmic plot of the pseudo-first-order $k_{\mathbf{0 b s}}$ vs 2-propanol concentration, which suggests first order rate dependence on 2-propanol concentration.

\section{----INSERT FIG. 4, Fig.5 and Table 1}

Concomitant generation of $\mathrm{H}_{2}$ was detected by the appearance of a singlet at $\delta 4.60$ in

the ${ }^{1} \mathrm{H}$ NMR spectrum for the reaction between 1 and 2-propanol in $\mathrm{CDCl}_{3}$ (verified by passing gaseous $\mathrm{H}_{2}$ through the same sample). Additionally, the formation of trace amounts of $\mathrm{CHDCl}_{2}$ was detected in $\mathrm{CDCl}_{3}$ solutions as a characteristic pattern of three lines of equal intensity centered at $\delta 5.33$, resulting from the spin-spin coupling between proton and deuterium nuclei. The genesis of $\mathrm{H}_{2}$ and $\mathrm{CHDCl}_{2}$ under these conditions could be ascribed to the formation of a short-lived metal hydride species [26]. The effect of deuterium substitution in the alcohol molecule was investigated to determine the source of the transferred hydrogen atom, through comparison of the reaction rates of 1 with 2-propanol vs $\left(\mathrm{CD}_{3}\right)_{2} \mathrm{CD}-\mathrm{OD}$ [27]. The calculated value of Kinetic Isotope Effect (KIE) is $k_{\mathbf{o b s}, \mathbf{H}} / k_{\mathbf{o b s}, \mathbf{D}}=2.0(3)$ at $-11^{\mathbf{0}} \mathrm{C}$ (see Fig. $6(\mathrm{~A})$ ). The observed rate constants for the reactions of $\mathbf{1}$ with 2-propanol-OD and $\mathbf{1}$ with proteo-2-propanol were equal within experimental error; therefore, the KIE value was 1 . The KIEs have also been estimated for the oxidation reactions of ethanol and methanol (Fig.6).

\section{INSERT FIG. 6}

Analysis of the reaction rate of 1 with $2.2 \mathrm{M}$ ethanol in $\mathrm{CH}_{2} \mathrm{Cl}_{2}$ yields the pseudo-first order rate constant $k_{\text {obs }}$ of $5.1 \times 10^{-4} \mathrm{~s}^{-1}$. The effect of deuterium substitution on the rate is determined by comparing the reaction of 1 with ethanol and with $\mathrm{CD}_{3} \mathrm{CD}_{2} \mathrm{OD}$. The obtained 
value of $k_{\mathbf{o b s}, \mathbf{H}} / k_{\mathbf{o b s}, \mathbf{D}}$ is $6.8(9)$ at $-11^{\mathbf{0}} \mathrm{C}$ (Fig. $\left.6(\mathrm{~B})\right)$. The kinetic isotope effect for the reaction of 1 with $\mathrm{CH}_{3} \mathrm{CH}_{2} \mathrm{OD}$ versus $\mathrm{CH}_{3} \mathrm{CH}_{2} \mathrm{OH}$ is equal to 1 .

Analysis of the combined KIE data suggests that $\mathrm{CH}$ bond cleavage at the $\beta$-carbon in the alcohol molecule (rather than in $\mathrm{OH}$ bond cleavage) is likely to be involved in the RDS of the overall reaction [27]. Comparatively, for the methanol-catalyzed decomposition of $\mathrm{HIr}\left(\mathrm{OCH}_{3}\right) \mathrm{Cl}\left(\mathrm{PMe}_{3}\right)_{3}$ to $\mathrm{H}_{2} \mathrm{IrCl}\left(\mathrm{PMe}_{3}\right)_{3}$ and formaldehyde, $\beta$-hydrogen elimination was proposed as the RDS, with observed KIE of 2.4 [28]. Activation parameters determined for that process were similar to the present study in terms of $\Delta \mathrm{H}^{{ }_{\text {obs }}}=24 \mathrm{kcal} / \mathrm{mol}$ (11 for this study) and $\Delta \mathrm{G}^{{ }_{\text {obs }}}(298)=24 \mathrm{kcal} / \mathrm{mol}$ (19 for this study), but different for $\Delta \mathrm{S}^{{ }_{\text {obs }}}=0 \mathrm{eu}$ (vs -19 for this study). The difference in entropic contribution may be a consequence of the preequilibrium step that takes place in the ruthenium system. Additionally, the large error associated with determination of the entropic factor, should be considered [25, 29].

Several researchers examined the formation and oxidative decomposition of alkoxo complexes, leading to metal hydrides and aldehydes or ketones, via a $\beta$-hydrogen elimination step [10,11]. A related example, of the ionic hydrogenation of ketones, has been reported by Bullock's group [30]:

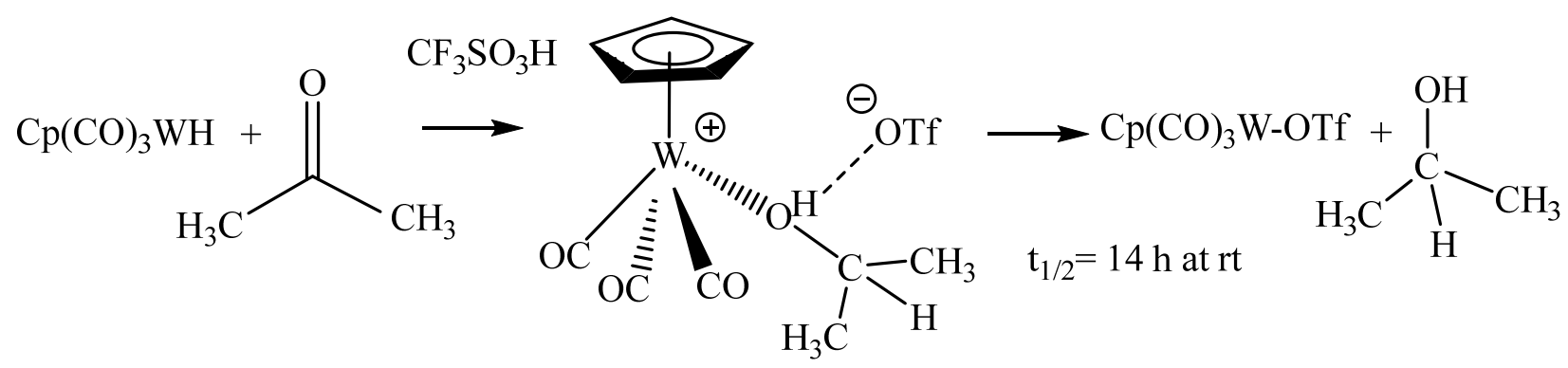

The overall reaction (Eq. 5) between a tungsten hydride complex, $\mathrm{CpHW}(\mathrm{CO})_{3}$, and acetone, in the presence of triflic acid results in formation of 2-propanol and $\mathrm{Cp}(\mathrm{CO})_{3} \mathrm{~W}(\mathrm{OTf})$. The formal sources of $\mathrm{H}^{+}$and $\mathrm{H}^{-}$in this case are HOTf and $\mathrm{HW}(\mathrm{CO})_{3} \mathrm{Cp}$, respectively. Therefore, in 
terms of this example the reaction between ruthenium triflate complex $\mathbf{1}$ and 2-propanol in the present study can be classified as reverse ionic hydrogenation, since it leads to the formation of acetone and an invoked, unstable metal-hydride species. Metal hydride-complexes have been observed to decompose with a release of $\mathrm{H}_{2}$ and metal-metal bond formation [31]. Additionally, a number of reports describe late transition metal complex reactions with alcohols, leading to aldehydes or ketones and hydrido products without observation of an alkoxo intermediate [32].

The capacity of NO to reversibly change bonding modes between linear and bent has been considered as an important tool for catalysis. The linear-to-bent transition oxidizes the metal center by two electrons and facilitates coordination of an additional ligand, while the bent-to-linear transition reduces the complex by two electrons and favors dissociation of a ligand, with stabilization of the resulting complex $[33,34]$. Milstein investigated $\mathrm{Ru}(0) / \mathrm{Ru}(\mathrm{II})$ pincer nitrosyl complexes which catalytically dehydrogenate alcohols to form esters via the proposed transient hydride pathway [35]. This system shows both bent and linear modes of the nitrosyl, which facilitate reversible redox transformations at the metal center. The potential involvement of NO bonding changes at the metal center should not be excluded from consideration in the case of $\mathrm{Cp}^{*} \mathrm{Ru}(\mathrm{NO})$ complexes reactivity. However, in the case of the $\mathrm{Cp} * \mathrm{Ru}(\mathrm{NO})$ system, the changing electronic environment on the metal center does not manifest itself significantly in the X-ray structures. The binding mode of NO deviates from linearity, with $\angle \mathrm{Ru}-\mathrm{N}-\mathrm{O}$ ca. $160^{\circ}$, both in starting material and in diol-bound species (complexes 1 and 3). For comparison, in the Milstein system the $\angle \mathrm{Ru}-\mathrm{N}-\mathrm{O}$ values ranges from $130^{\circ}$ for the bent NO complexes to $178^{\circ}$ in close-to-linear NO complexes [35]. The two electron redox process in our $\mathrm{Ru}(\mathrm{II}) / \mathrm{Ru}(0)$ system ultimately yields the reduced dimeric complex $\mathbf{2}$, with two symmetrical bridging nitrosyls, displaying a much lower $v_{\mathrm{NO}}$ of $1430 \mathrm{~cm}^{-1}$, as expected for this mode of NO binding [16,17]. 
The overall redox process of the $\mathrm{Cp}^{*} \mathrm{Ru}(\mathrm{NO}) \mathrm{OTf}_{2}$ complex 1 with alcohols is shown in Scheme 1. The initial step involves alcohol coordination to the ruthenium center. It is followed by $\beta$-hydrogen elimination from the coordinated alcohol molecule, leading to the formation of the aldehyde or ketone and a metal hydride species. Next, reductive elimination from the metal hydride occurs, ultimately resulting in the formation of the dimeric $\mathrm{Ru}(0)$ complex $[\mathrm{Cp} * \mathrm{Ru}(\mu-\mathrm{NO})]_{2}$.

\section{-Insert Scheme 1}

The dissociation of the second triflate appears critical as it generates a free coordination site, facilitating $\beta$-hydrogen elimination from the bound alcohol molecule. This is expected to result in the release of an aldehyde or ketone molecule and the formation of invoked metal-hydride intermediate A. The latter species is not directly observed, but proposing its existence is warranted based on the confirmed formation of $\mathrm{CHDCl}_{2}$ when the reaction is run in $\mathrm{CDCl}_{3}$, in addition to $\mathrm{H}_{2}$ generation presumably from the hydride decomposition. The results of kinetic studies, in particular, the first order of the reaction with respect to the $\mathrm{Ru}(\mathrm{II})$ starting complex, and the considerable primary kinetic isotope effect, support the involvement of $\beta$-hydrogen elimination in the RDS of the reaction. The fact that the reaction is first order in 2-propanol is also consistent with the proposed scheme. The proton released from the $\mathrm{OH}$ group may be absorbed in a close ionic pair with the triflate anion, effectively liberating triflic acid, which is absorbed in reaction with the excess of alcohol. The determination of the structures of the transient metal hydride complex $\mathbf{A}$ and the reduced mono-nuclear short-lived complex $\mathbf{B}$ will require further experimental work, as these species elude direct observation by spectroscopic methods. Finally, the coupling of two $[\mathrm{Cp} * \mathrm{Ru}(\mathrm{NO})]$ fragments generates the dimeric product 2, $[\mathrm{Cp} * \mathrm{Ru}(\mu-\mathrm{NO})]_{2}$, and appears to be rapid, since the overall reaction rate is first, rather than second order with respect to $\mathrm{Ru}(\mathrm{II})$ complex. 


\section{Conclusion}

We have presented the study of $\mathrm{Cp}^{*} \mathrm{Ru}(\mathrm{NO}) \mathrm{OTf}_{2}$ reactivity with alcohols, in which a new facile synthetic route to the $\left[\mathrm{Cp}^{*} \mathrm{Ru}(\mu-\mathrm{NO})\right]_{2}$ dimer was discovered. The equilibrium investigation of triflate dissociation and alcohol binding to a ruthenium center in solution determined this process to be exothermic and entropically unfavorable. The chelate-stabilized adduct of $\mathrm{Cp} * \mathrm{Ru}(\mathrm{NO})$ with a diol ligand was isolated and structurally characterized. Finally, kinetics of the alcohol oxidation and metal center reduction has been probed by ${ }^{1} \mathrm{H}$ NMR methods, and a mechanism, including a $\beta$-hydrogen elimination rate determining step, was proposed. Further investigation is required to gain more detailed mechanistic insight and further develop the potential catalytic applications.

\section{Experimental}

\subsection{Materials and methods}

Standard Schlenk techniques were employed in all procedures. The nitrogen reaction atmosphere was purified by passing through scavengers for water (Aquasorb, Mallinckrodt) and oxygen (Catalyst R3-11, Chemical Dynamics, So. Plainfield, N.J.). Organic solvents were distilled under nitrogen over appropriate drying agents prior to use. The water used was purified and deionized (NANO-pure Ultrapure Water System) and saturated with $\mathrm{N}_{2}$ gas prior to use. All chemical reagents were used as received from Aldrich unless stated otherwise. Complex 1 was synthesized according to published procedure [14]. Infrared spectra were recorded on a Mattson Polaris-Icon FT-spectrometer.

The ${ }^{1} \mathrm{H},{ }^{2} \mathrm{H},{ }^{13} \mathrm{C}$ and ${ }^{19} \mathrm{~F}$ NMR spectra were recorded on a Bruker ARX-400 NMR spectrometer operating at $400 \mathrm{MHz}\left({ }^{1} \mathrm{H}\right), 61.42 \mathrm{MHz}\left({ }^{2} \mathrm{H}\right), 100.62 \mathrm{MHz}\left({ }^{13} \mathrm{C}\right)$, and $376.2 \mathrm{MHz}$ $\left({ }^{19} \mathrm{~F}\right)$. The residual solvent peak of $\mathrm{CDCl}_{3}$ was used as the internal NMR standard $\left({ }^{1} \mathrm{H} \delta 7.24\right.$; $\left.{ }^{13} \mathrm{C} \delta 77.0 \mathrm{ppm}\right)$, as well as the residual peak of HDO $\left({ }^{1} \mathrm{H} \delta 4.70\right)$. Spectra were recorded at 298 
$\mathrm{K}$ unless otherwise stated. The ${ }^{19} \mathrm{~F}$ chemical shifts were referenced externally to $\mathrm{CFCl}_{3}(\delta 0.0)$ or internally to 3,5-bis(trifluoromethyl)benzene ( $\delta-63.2)$; a relaxation delay of $12 \mathrm{~s}\left(>5 T_{1}\right)$ was used to optimize the integration [36]. Free OTf appears at $\delta-78.6$ in $\mathrm{CH}_{2} \mathrm{Cl}_{2}$ and $\delta-78.0$ in $\mathrm{H}_{2} \mathrm{O}$, regardless of the counter-ions present. NMR spectra in $\mathrm{CH}_{2} \mathrm{Cl}_{2}$ and $\mathrm{H}_{2} \mathrm{O}$ were measured using solvent pre-saturation techniques and were shimmed and referenced to the signals from $\mathrm{CDCl}_{3}$ sealed inside a $1.5 \mathrm{~mm}$ capillary located concentrically inside the 5-mm NMR tube. When necessary, 5-mm NMR tubes with re-sealable Teflon valves were used (Brunfeld Co., Bartlesville, OK). The chemical shifts reported for the complexes in $\mathrm{CH}_{2} \mathrm{Cl}_{2}$ and $\mathrm{H}_{2} \mathrm{O}$ are identical to those in the analogous deuterated solvents. The equilibrium and kinetic studies utilized ${ }^{19} \mathrm{~F}$ and ${ }^{1} \mathrm{H}$ NMR spectroscopy. The temperature inside the VT-NMR probe was calibrated according to literature procedures [37]. For Van't Hoff analyses, the samples were allowed to thermally equilibrate at the desired temperatures before spectra were recorded (15$120 \mathrm{~min}$ ). Melting points were measured with a Mel-Temp device (Laboratory Devices) in open capillaries and are uncorrected. Combustion analysis was performed by Atlantic Microlab, Inc. Norcross, GA.

4.2 Synthesis of $\left[\mathrm{Cp} * \mathrm{Ru}(\mathrm{NO})\left(\mathrm{HO}-\mathrm{CH}_{2} \mathrm{CH}_{2}-\mathrm{OH}\right)\right][\mathrm{OTf}]_{2}$ (3) [15b]

A portion of $\mathrm{HO}-\mathrm{CH}_{2} \mathrm{CH}_{2}-\mathrm{OH}\left(0.01 \mathrm{~cm}^{3}, 0.213 \mathrm{mmol}, 3\right.$ equiv $)$ was added to a stirred solution of $40 \mathrm{mg}$ of $\mathbf{1}\left(0.071 \mathrm{~cm}^{3}\right)$ in $10 \mathrm{~cm}^{3}$ of $\mathrm{CHCl}_{3}$. A red precipitate formed within $5 \mathrm{~min}$ and the initially purple solution became almost colorless. The supernatant was decanted and the precipitate recrystallized from a $\mathrm{CH}_{2} \mathrm{Cl}_{2} /$ hexane mixture at $-40{ }^{\circ} \mathrm{C}$ yielding $30 \mathrm{mg}(0.050 \mathrm{mmol}$, $70 \%$ ) of analytically pure complex 2 . X-ray quality crystals were grown by slow evaporation of the $\mathrm{CDCl}_{3}$ solution. The $\mathrm{CHCl}_{3}$ solvent used in this reaction should be completely free from EtOH traces, otherwise isolation of the crystalline 2 becomes difficult due to the reaction between 1 and EtOH [38]. ${ }^{1} \mathrm{H}$ NMR $\left(\mathrm{CH}_{2} \mathrm{Cl}_{2}\right): \delta 1.93$ (s) $\left(15 \mathrm{H}, \mathrm{Cp}^{*}\right) ; \delta 1.88$ (s) (15H, $\mathrm{Cp}^{*}$ minor amounts of 1 in equilibrium with 2); $\delta 4.23$ (broad) (2H, $\left.\mathrm{HO}-\mathrm{CHH}_{a}-\mathrm{CH} H_{a}-\mathrm{OH}\right) ; \delta 3.35$ (broad) (2H, HO-CHb $\mathrm{H}-\mathrm{CH} b \mathrm{H}-\mathrm{OH}) ; \delta 11.13(2 \mathrm{H}, 2 \mathrm{OH}) ;{ }^{13} \mathrm{C} \mathrm{NMR}\left(\mathrm{CH}_{2} \mathrm{Cl}_{2}\right): \delta 119.8$ (q, $\left.\mathrm{OSO}_{2} \underline{\mathrm{CF}}_{3}, \mathrm{~J}_{\mathrm{C}-\mathrm{F}}=318.4 \mathrm{~Hz}\right) ; \delta 113.9\left(\underline{\mathrm{C}_{5} \mathrm{Me}}\right) ; \delta 67.8\left(\mathrm{HO}-\underline{\mathrm{CH}_{2}}-\underline{\mathrm{CH}}_{2}-\mathrm{OH}\right), \delta 9.6\left(\mathrm{C}_{5} \underline{\underline{\mathrm{Me}}}\right)$; ${ }^{19} \mathrm{~F}\left\{{ }^{1} \mathrm{H}\right\}$ NMR $\left(\mathrm{CH}_{2} \mathrm{Cl}_{2}\right): \delta-78.6$; IR (nujol) vNo $1820 \mathrm{~cm}^{-1}$ (vs), IR $\left(\mathrm{CH}_{2} \mathrm{Cl}_{2}\right)$ vNo $1790 \mathrm{~cm}^{-1}$ (vs); mp $131^{\circ} \mathrm{C}$; Anal. Calcd for $\mathrm{C}_{14} \mathrm{H}_{21} \mathrm{NO}_{9} \mathrm{RuS}_{2} \mathrm{~F}_{6}(626)$ : C, 26.80; H, 3.40; N, 2.20; Found: C, 26.82; H, 3.43; N, 2.18 . 


\subsection{Reaction of 1 with 2-propanol.}

2-propanol $\left(10 \mathrm{~cm}^{3}\right)$ was added via syringe to a Schlenk flask charged with $100 \mathrm{mg}$ $(0.177 \mathrm{mmol})$ of solid $\mathbf{1}$ and a stir-bar. A red precipitate formed after $5 \mathrm{~min}$ of stirring. The solution was filtered through a frit under $\mathrm{N}_{2}$ and the solid was washed with cold hexane and dried in vacuo, yielding $44 \mathrm{mg}$ of $[\mathrm{Cp} * \mathrm{Ru}(\mathrm{NO})]_{2}(0.082 \mathrm{mmol}, 93 \%)$. ${ }^{1} \mathrm{H} \mathrm{NMR}\left(\mathrm{C}_{6} \mathrm{D}_{6}\right.$, $\left.\mathrm{CH}_{2} \mathrm{Cl}_{2}\right)$ and ${ }^{13} \mathrm{C}$ NMR $\left(\mathrm{C}_{6} \mathrm{D}_{6}\right)$ spectra are identical to published data. ${ }^{16 \mathrm{~b}}$

\subsection{Exchange equilibria studies for the OTf substitution in $\mathbf{1}$ by ethanol, methanol and ethylene glycol.}

The $\mathrm{K}_{\text {eq }}$ determination for eq. 2 from ${ }^{19} \mathrm{~F}$ NMR spectra were performed according to the earlier reported procedures described for [RuCp*NO] complexes [30]. Substitution reactions with alcohols were studied in the presence 1.7-2 equiv alcohols to avoid oxidation processes. The ${ }^{19} \mathrm{~F}$ NMR exchange equilibria studies specifically for eq. 3 at varying concentrations of $\mathbf{1}$, ethylene glycol and excess of triflate (added as alkyl ammonium salt) are described in detail in supplemental information for this paper. As in previously reported experiments, the nonreactive 3,5-bis(trifluoromethyl)benzene was used as internal standard (with $\delta$-63.2 signal in ${ }^{19} \mathrm{~F}$ NMR spectrum in dichloromethane) in order to ensure the reliability and consistency of the integration.

\subsection{Kinetics Experiments}

A $\mathrm{CH}_{2} \mathrm{Cl}_{2}$ solution of 1 was prepared in a nitrogen glovebox using standard dilution techniques and a Fisher/Ainsworth (1 mg) balance. A Hamilton microliter syringe was used to add solutions at room temperature to $5 \mathrm{~mm}$ Pyrex NMR tubes, and the height of the solution in the tubes was checked for consistency. Usually each tube contained $0.500 \mathrm{~cm}^{3}$ of a $0.014 \mathrm{M}$ solution of 1 . The solutions of alcohols in $\mathrm{CH}_{2} \mathrm{Cl}_{2}$ of the desired concentration was also prepared in the glove box and placed in separate vials. Prior to monitoring the reaction between 1 and alcohol, the NMR tube containing the solution of $\mathbf{1}$ in $\mathrm{CH}_{2} \mathrm{Cl}_{2}$ was placed in a Dewar with hexane-liquid $\mathrm{N}_{2}$ slush for $2 \mathrm{~min}$. The pre-chilled alcohol solution in $\mathrm{CH}_{2} \mathrm{Cl}_{2}$ (usually $0.150 \mathrm{~cm}^{3}$ ) was added to the tube via syringe through a septum. The tube was shaken several times to achieve homogeneity of the solution and quickly placed in the NMR probe, maintained at the desired temperature. Spectra were recorded using at least five $T_{1}$ periods between pulses 
to assure reliable quantitative results. The total integral over the signals of the starting $\mathbf{1}$ and alcohol coordinated complexes was used to deduce the amount of $\mathrm{Ru}$ (II) species present in solution. In all cases, integrals and peak-heights were referenced to an internal standard signal of $\mathrm{C}_{6} \mathrm{H}_{6}$ that was added to the $\mathrm{CH}_{2} \mathrm{Cl}_{2}$ used in the sample preparation. In each set of experiments the acquisition parameters were left constant. The interval between the acquisition of individual data sets was changed as needed. The reaction was followed at $-47^{\circ} \mathrm{C}$ for ca. 2 half-lives of 1 , at $-41^{\circ} \mathrm{C}$ for ca. 2 half-lives of 1 , at $-36^{\circ} \mathrm{C}$ for ca. 3 half-lives of 1 , at $-31{ }^{\circ} \mathrm{C}$ for ca. 3 half-lives of $\mathbf{1}$, at $-25^{\circ} \mathrm{C}$ for ca. 4 half-lives of $\mathbf{1}$, at $-19^{\circ} \mathrm{C}$ for ca. 5 half-lives of $\mathbf{1}$. In these experiments there was no deviation from the first-order dependence of the rate on [1]. In all reactions only starting material and $[\mathrm{Cp} * \mathrm{Ru}(\mu-\mathrm{NO})]_{2}$ were observed at the end of the experiments. The presence of acetone was detected by its characteristic singlet at $\delta 2.14$. The values of rate constants were reproducible within $10-15 \%$ inaccuracy.

\section{Acknowledgements.}

Contributions to support of this research at various stages by NSF (CHE-9215872 to JLH at Utah State University), ACS PRF (44692.01-GB) and Research Corporation (CC6755), as well as by Ithaca College and Utah State University, are gratefully acknowledged. The authors are also greatly indebted to Mr. Benjamin Morse and Ms. Megan Wirth for their invaluable help with preparation of the manuscript.

\section{Supplementary data.}

Details of thermodynamics studies, including listings of the $\mathrm{K}_{\mathrm{eq}}$ values for the Van't Hoff analyses and methods for the measurements and calculations are available. 
References.

[1] "Principles of Organotransition Metal Chemistry", J.P. Collman, L.S. Hegedus, J. R. Norton, R.G. Finke, University Science Books, Mill Valley, CA, 1987.

[2] J.A. Gladysz, B.R. Bedford, M. Fujita, F.P. Gabbaï, K.I. Goldberg, P.L. Holland, J.K. Kiplinger, K.J. Krische, J. Louie, C.C. Lu, J.R. Norton, M.A. Petrukhina, T. Ren, S.S. Stahl, T.D. Tilley, C.E. Webster, C.M. White, G.T. Whiteker, Organometallics 33(7) (2014), 1505; A. Rouhi A. Chem. Eng. News 73(25) (1995) 32.

[3] J. Zhao, H. Hesslink, J. Hartwig, J. Am. Chem. Soc. 123 (2001) 7220.

[4] K. Yamaguchi , J. Kim , J.He J., Mizuno N. J. of Catalysis 268 (2009) 343-349.

[5] T. Kondo,Y. Kimura , H. Yamada , A. Toshimitsu A. "Transition Metal Catalysis in Aerobic Alcohol Oxidation“ RSC Green Chemistry Book Series, RSC Publishing (2014), Chapter 3;

F.A. Carey, J.A. Sundberg, "Advanced Organic Chemistry", R. J. Plenum Press: New York, 3rd Ed; Chapter 12 (1993) "Oxidations" , p. 627-628 and references therein; K. Sharpless, R. Michaelson J. Am. Chem. Soc. 95 (1973) 6136; Y. Gao, R. Hanson, J. Klunder. S. Ko, H. Masamune, K.B. Sharpless J. Am. Chem. Soc. 109 (1987) 1525

[6] Q. Kang, J.Luo, Y.Bai, Z.Yang , Z. Lei J. Organomet. Chem. 690 (2005) 6309; K. Ren, B.Hu, M. Zhao, Y. Tu, X. Xie, Z. Zhang J. Org. Chem. 79(5) (2014) 2170; I. Ansari, R; Gree R. Organic Letters 4 (9) (2002) 1507; H. Shen, L.Ying, H. Jiang, Z. Judeh Int. J. Mol. Sci. 8 (2007), 505; J. Jiang, J. Du, Z. Wang, Z. Zhang, X. Xu, G. Zheng, Y. Ji Tetrahedron letters 55 (2014) 1677 ; A. Sabbatini, L. Martinas, K. Mahmudov, M. Kopylovich, M. Drew, C. Pettinari, A. Pombeiro Catalysis communications 48 (2014) 69-72; K. Coleman, L. Bedel, J. Osborn Comptes Rendus 3 (2000) 765; D. Pearson, N. Conley, R.Waymouth Organomet. 30 (2011) 1445; J. Mueller, M. M. Sigman J. Am. Chem. Soc. 125 (23 (2003) 7005; J. Mueller, C. Goller, M. Sigman J. Am. Chem. Soc. 126 (31) (2004) 9724; L. Liu, M. Yu, B. Wayland, X. Fu Chem. Commun. 46 (2010), 6353; G. Zhang, S. Hanson Org. Lett., 15 (3) (2013) 650; J. Ritter, R.

Bergman J. Am. Chem. Soc.120 (27), (1998) 6826.

[7] H. Li, G. Lu, J. Jiang, F. Huang, Z.X. Wang 30(8), Organomet., (2011) 2349 ; S.

Chakraborty, P.O. Lagaditis, M. Förster, E.A. Bielinski, N. Hazari, M.C. Holthausen, W.D. Jones, S. Schneider ACS Catalysis, 4(11) (2014) 3994.

[8] M.M. Konnick, B.A. Gandhi, I.A. Guzei, S.S. Stahl Ang.Chemie, 118(18), (2006) 2970;

B.A.Steinhoff, S.R. Fix, S.S. Stahl J. Am. Chem. Soc., 124(5) (2002) 766.

[9] O. Blum, D. Milstein, J. Organomet. Chem. 593 (2000) 479.

[10] B.A. Steinhoff, I.A. Guzei, S.S. Stahl J. Am. Chem. Soc., 126(36) (2004) 11268.

[11] C. Krug, J.F. Hartwig J. Am. Chem. Soc., 124(8) (2002) 1674.

[12] P.L. Theofanis, W.A. Goddard III Organometallics, 30(18), (2011). 494; H. Zhao, A. Ariafard, Z. Lin, Z. Organometallics, 25(4) (2006) 812

[13] (a) T. Hollis, N. Robinson, B. Bosnich (1992), Organometallics, 11, 2645. (b) T. Hollis , N. Robinson , B. Bosnich J. Am. Chem. Soc., 114 (1992) , 5464. (c) P. Bonnesen, C. Puckett, R. Honeychuck, W. Hersh, J. Am. Chem. Soc. 111, (1989) 6070. (d) R. Honeychuck, P. Bonnesen , J. Farahi, W. Hersh , J. Org. Chem. 52 (1987), 5293; W. Odenkirk , A. Rheingold, B. Bosnich J. Am. Chem. Soc. 114 (1992) , 6392; B. Trost, A. Indolese, T. Miller, B. Treptow J Am. Chem. Soc. 117 (1995), 615; G.A. Lawrance Chem. Rev. 86 (1), (1986)

[14] A.Svetlanova- Larsen, C.R. Zoch , J.L. Hubbard Organometallics 15 (1996), 3076. 
[15] a) C.R. Zoch, C.R., PhD. Dissertation, (1993) Utah State University; b) A. SvetlanovaLarsen, A.; PhD. Dissertation (1997) Utah State University.

[16] a) J. Chang, R. Bergman J. Am. Chem. Soc. 109 (1987), 4298; b) J.L. Hubbard, A.

Morneau, R.M. Burns,C.R. Zoch J. Am. Chem. Soc.113 (1991), 9176.

[17] M. Pearsall, M. Gembicky, P. Dominiak, A. Larsen, P. Coppens Acta Crystallogr. Sect. E: Struct. Rep. Online 63, (2007) 2596. The x-ray studies of the complex were complicated by its propensity to form twinned crystals.

[18] J.C. Pouchert, J. Behnke, J., "The Aldrich Library of $13 \mathrm{C}$ and 1H FT NMR Spectra", 1st Ed., v. 1, 727-750.)

[19] See supplemental materials for the thermodynamic studies details, including representative explicit values of equilibrium constants and Van't Hoff plots used in these analyses.

[20] J.L. Hubbard, R.M. Burns J. Am. Chem. Soc. 116 (1994), 9514

[21] In contrast, iridium and rhenium $\mathrm{Cp}^{*}$ systems readily form alkoxides. For example : D.

Glueck, L.Winslow, R. Bergman Organometallics 10 (1991), 1462;

[22] S. Munie , A.S. Larsen, M. Gembicky Acta Crystallogr. Sect. E: Struct. Rep. Online 64 (2008), 293.

[23] I. Olovsson, P.Jonsson The Hydrogen Bond; P. Schuster, G. Zundel ; C. Sandorfy, C. Eds.; North-Holland: New York, 1976, Chapter 8. Review of hydrogen bonding and its classification: P. Gilli ; V. Bertolasi, V.Ferretti, G. Gilli J. Am. Chem. Soc., 116, (1994) 909. [24] M.D. Mingos Nitrosyl Complexes in Inorganic Chemistry, Biochemistry and Medicine I (Structure and Bonding) 2014, Springer-Verlag Berlin Heidelberg Ed; T.W. Hayton, P. Legzdins , W.B. Sharp, 102 (4),Chem. Rev., (2002) 935; H. Rothfuss, J. Huffman, K. Caulton J. Am. Chem. Soc. 116 (1994) 187; D. Gusev, R. Kulhman, J. Rambo, H. Berke, O. Eisenstein, K. Caulton J. Am. Chem. Soc. 117 (1995) 281; T. Johnson, K. Folting, W. Streib, J. Martin, J. Huffman, S. Jackson, O. Eisenstein, K. Caulton Inorg. Chem. 34 (1995) 488; K. Caulton (1994) 25.

[25] J.W. Moore; R.G. Pearson; Kinetics and Mechanism Chapter 2 (1981) John Wiley \& Sons, 3rd Ed.; J.H. Espenson, Chemical Kinetics and Reaction Mechanisms (1995). New York: McGraw-Hill.

[26] B. James, R. Morris, P. Kvintovics Canadian Journal of Chemistry 64(5) (1986) 897. [27] L. Melander ; W.H. Saunders Reaction Rates of Isotopic Molecules; Chapters 5,6 (1980) John Wiley \& Sons.

[28] O. Blum, D. Milstein J. Am. Chem. Soc. 117 (1995), 4582.

[29] P.M. Morse, M. D. Spencer, S. R. Wilson, G. S. Girolami, 13 (1994) Organometallics 1646. [30]J. Song, D. Szalda, R. Bullock, C. Lawrie, M. Rodkin, J. Norton J. Angew. Chem., Int. Ed. Engl. 31 (1992), 1233; J. Song, D. Szalda, R. Bullock Organometallics 20 (15) (2001) 3337. [31] H. Bryndza, W. Tam Chem. Rev 88 (1998), 1163; C. Lau, S. Ng, G. Jia, Z. Lin Coord. Chem. Rev. 251 (17-20), 2223-2237; H. Berke, P.Burger, P. Comments on Inorganic Chemistry 16 (5) (1994) 279.

[32] D. Hoffman, D. Lappas, D. Wierda J. Am. Chem. Soc. 111 (1989), 1531; "Advanced Organic Chemistry", Carey, F. A.; Sundberg, R. J. Plenum Press:New York, 3rd Ed; 1993, Chapter 12 "Oxidations", p. 627-628 and references therein; Sharpless, K. B.; Michaelson, R. C. J. Am. Chem. Soc., 1973, 95, 6136. Gao, Y.; Hanson, R.M.; Klunder, J. M.; Ko, S. Y.; Masamune, H.; Sharpless, K. B. J. Am. Chem. Soc., 1987, 109, 1987. [33] H. Berke, P.Burger, P. Comments on Inorganic Chemistry 16 (5) (1994) 279. 
[34] Y. Jiang, B. Schirmer, O. Blacque, T. Fox, S. Grimme, H. Berke, J. Am. Chem. Soc. 135 (10) (2013) 4088.

[35] E. Fogler, M.A. Iron, J. Zhang, Y. Ben-David, Y. Diskin-Posner, G. Leitus, L.J.W.

Shimon, D. Milstein Inorg. Chem., 52 (19) ( 2013) 11469. This system shows both bent and linear modes of the nitrosyl, with an additional option of pincer ligand undergoing reversible dearomatization.

[36] A.S. Gordon, R.A. Ford John "The Chemists Companion" Wiley \& Sons, 1st Ed, 1972, 288.

[37] A. Van Geet Anal. Chem 42 (1970), 679.

[38] D.D. Perrin, W.L.F.Armarego, "Purification of Laboratory Chemicals" Pergamon Press, 3rd Ed., 1988, 121. 


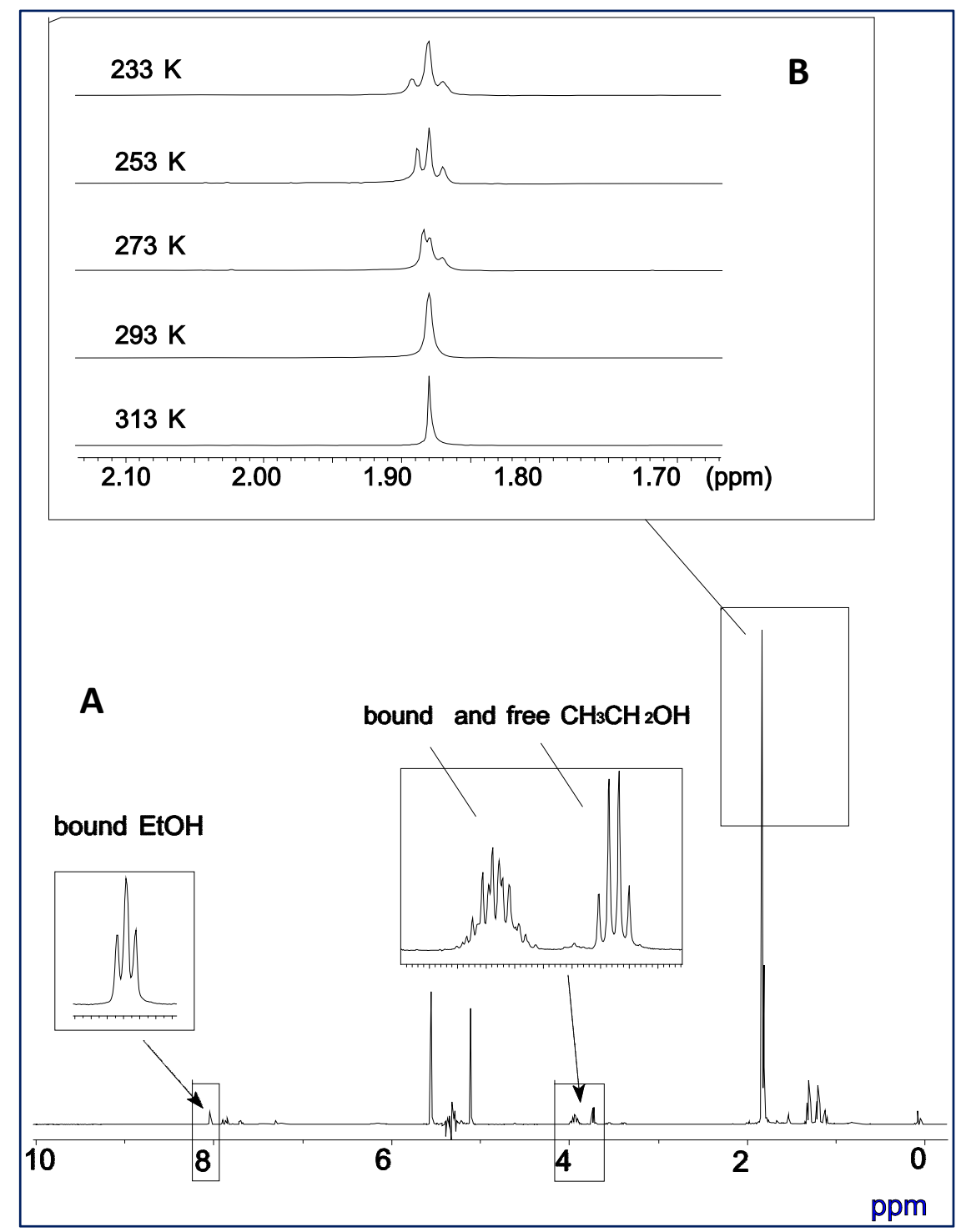

Figure 1. (A) ${ }^{1} \mathrm{H}$ NMR spectrum of $\mathbf{1}$ in $\mathrm{CH}_{2} \mathrm{Cl}_{2}$ in the presence of 2 equiv ethanol at $-20^{\circ} \mathrm{C}$. The resonance of the diastereotopic methylene group of the coordinated ethanol is observed as a multiplet appearing downfield from the methylene protons of free ethanol, with the bound hydroxyl signal appearing as a triplet at $\delta 8.15$. (B) The $\mathrm{Cp}^{*}$ resonance area of the ${ }^{1} \mathrm{H}$ NMR spectra at variable temperatures shows inter-conversion of $\left[\mathrm{Cp}^{*} \mathrm{Ru}(\mathrm{NO})(\mathrm{OTf})(\mathrm{EtOH})\right]^{+}$, complex $\mathbf{1}$, and $\left[\mathrm{Cp} * \mathrm{Ru}(\mathrm{NO})(\mathrm{EtOH})_{2}\right]^{2+}$. 


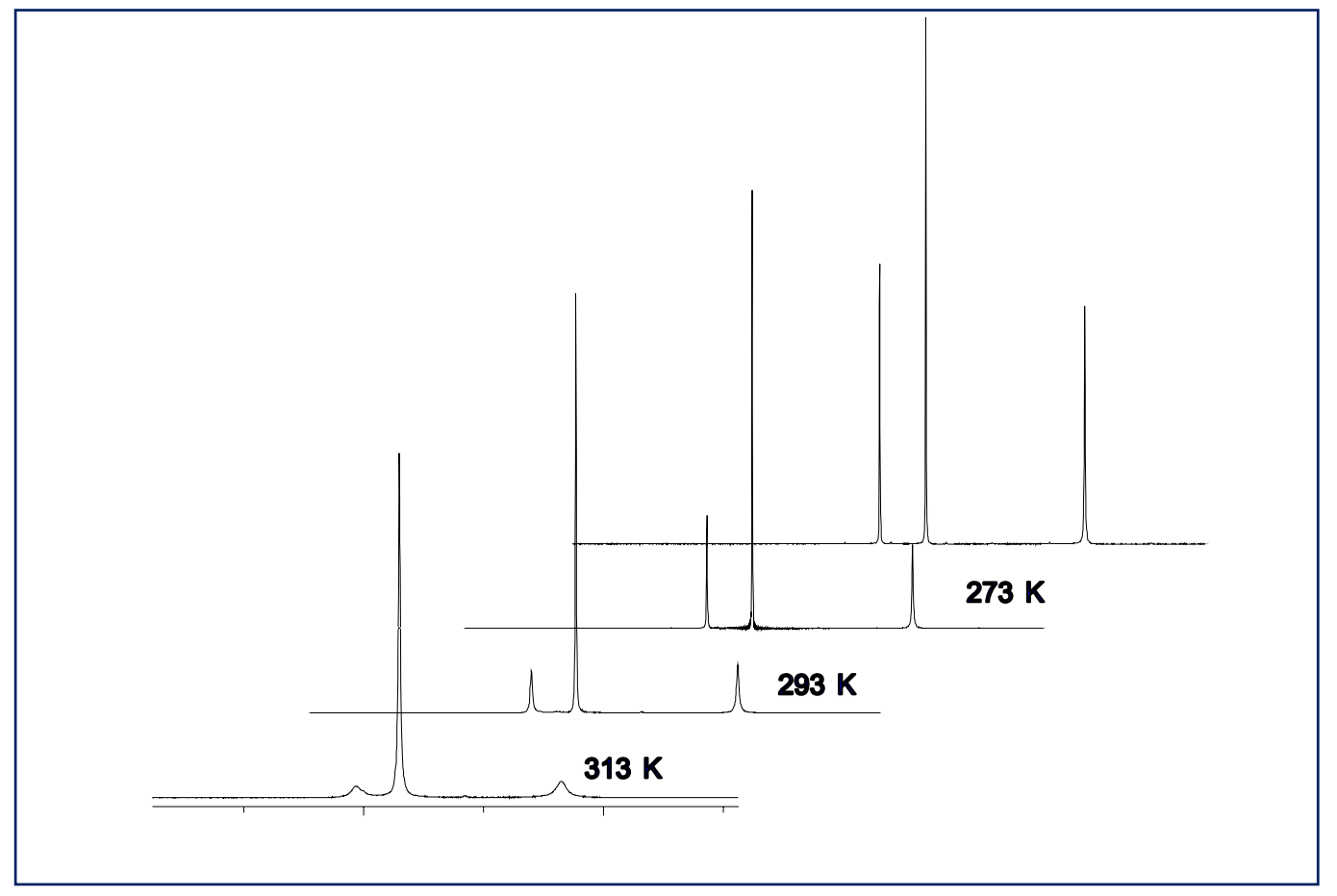

Figure 2. ${ }^{19} \mathrm{~F}$ NMR spectrum of $\mathbf{1}$ in $\mathrm{CH}_{2} \mathrm{Cl}_{2}$ in the presence of 2 equiv of ethanol at variable temperature between 253 and $313 \mathrm{~K}$. The addition of 1.5 equiv of simple alcohols (such as ethanol, methanol and 2-propanol) to a solution of $\mathrm{Cp}^{*} \mathrm{Ru}(\mathrm{NO})(\mathrm{OTf})_{2}$ 1) results in the decrease of the original $\delta-77.0$ signal of bound $\mathrm{OTf}^{-}$and the appearance of an upfield signal corresponding to free $\operatorname{OTf}^{\prime}(\delta-78.6)$ and a downfield signal resulting from $[\mathrm{Cp} * \mathrm{Ru}(\mathrm{NO})(\mathrm{OTf})(\mathrm{ROH})]^{+}$. The integral of the signal due to free OTf is greater than the integral of the signal from $[\mathrm{Cp} * \mathrm{Ru}(\mathrm{NO})(\mathrm{OTf})(\mathrm{ROH})]^{+}$in all cases, inferring the presence of a third ${ }^{19} \mathrm{~F}$ NMR silent complex $\left[\mathrm{Cp} * \mathrm{Ru}(\mathrm{NO})(\mathrm{ROH})_{2}\right]^{2+}$. 


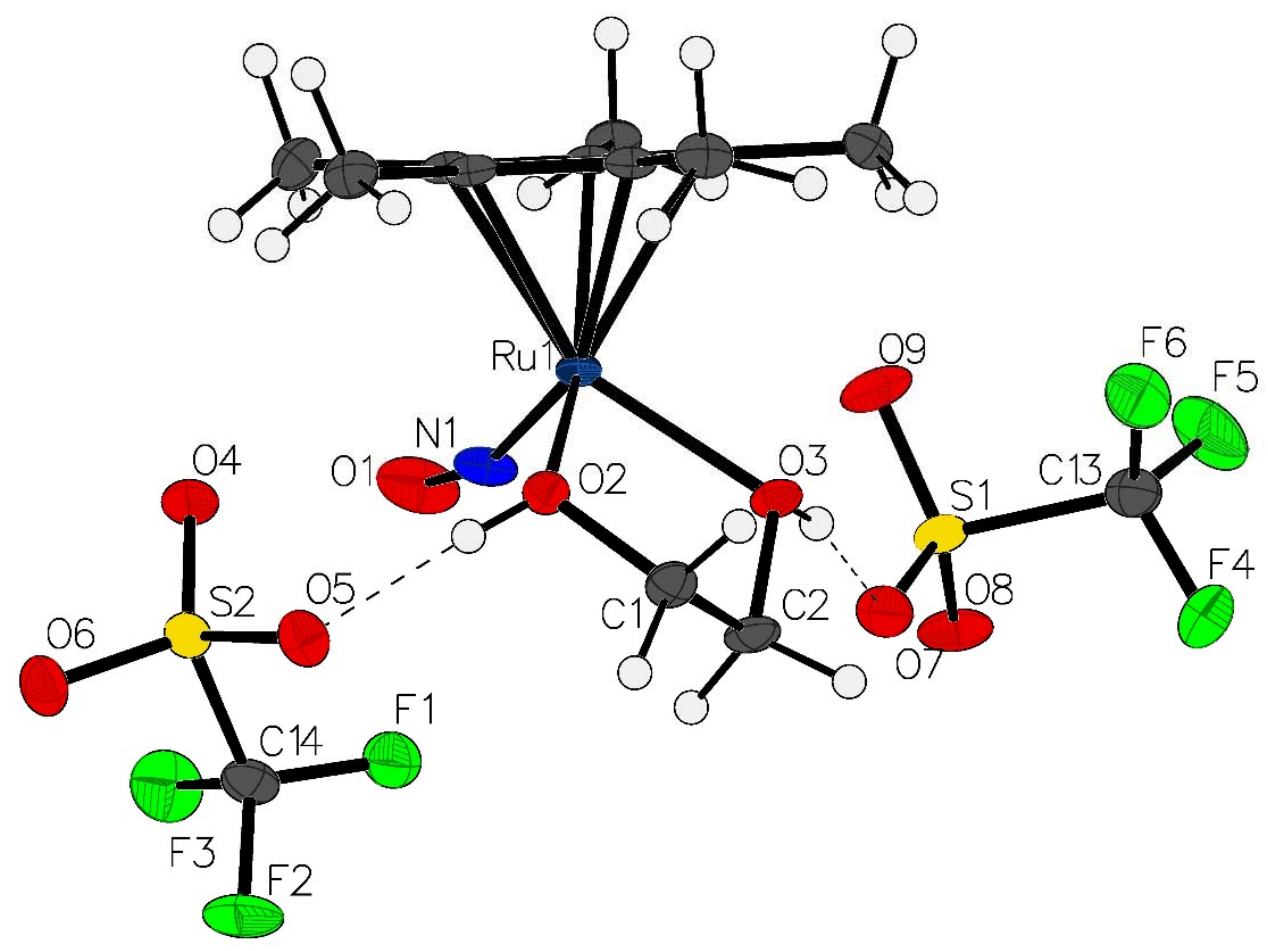

Figure 3. Thermal ellipsoid plot for complex salt 3 (shown at 50\% probability). The dashed lines represent hydrogen bonding. 

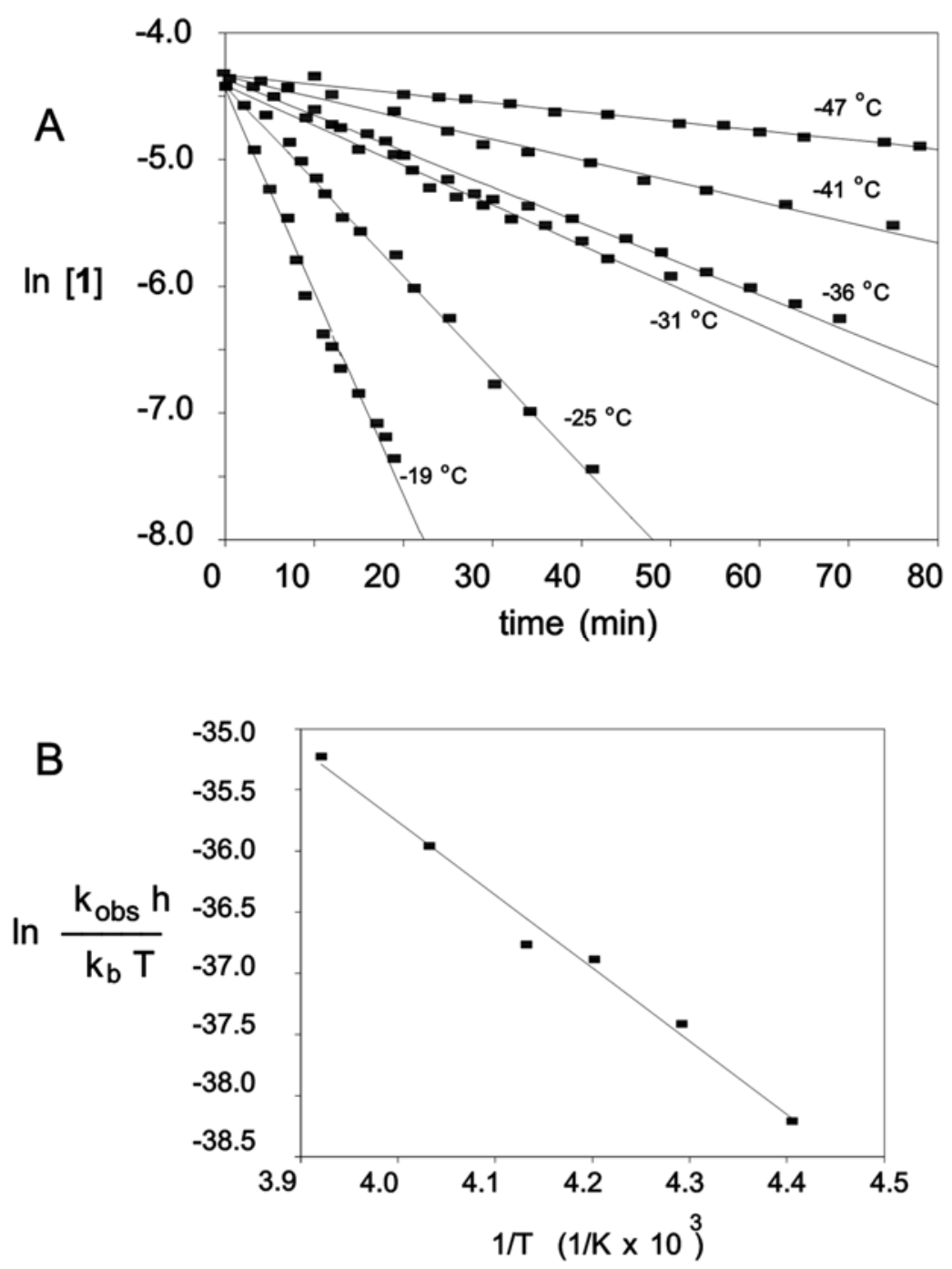

Figure 4. (A) Pseudo-first order plots for the reaction of 1 with 2-propanol in $\mathrm{CH}_{2} \mathrm{Cl}_{2}$. The measurements were performed for initial concentrations of $0.014 \mathrm{M}$ for complex 1 and $2.1 \mathrm{M}$ for 2-propanol, at temperature range between -19 and $-47^{\circ} \mathrm{C}$. A plot of $\ln [1]$ versus time $-19^{\circ} \mathrm{C}$ covers $>5$ half-lives of the reaction. Reproducibility of the $\mathrm{k}_{\text {obs }}$ were confirmed for the samples of varying initial concentration of 1 (between 0.006 and $0.016 \mathrm{M}$ ). The experimental error in determination of $k_{o b s}$ values is estimated at $15 \%$. ); (B) Eyring plot for the reaction of 1 with 2propanol in $\mathrm{CH}_{2} \mathrm{Cl}_{2}$. Activation parameters are $\Delta \mathrm{H}^{\neq}{ }_{\mathbf{o b s}}=11.9$ (5) $\mathrm{kcal} / \mathrm{mol}, \Delta \mathrm{S}^{\neq}{ }_{\mathbf{o b s}}=-24(6) \mathrm{eu}$, and $\Delta \mathrm{G}^{\neq}{ }_{\text {obs }}(298)=19(2) \mathrm{kcal} \mathrm{mol}^{-1}$ 


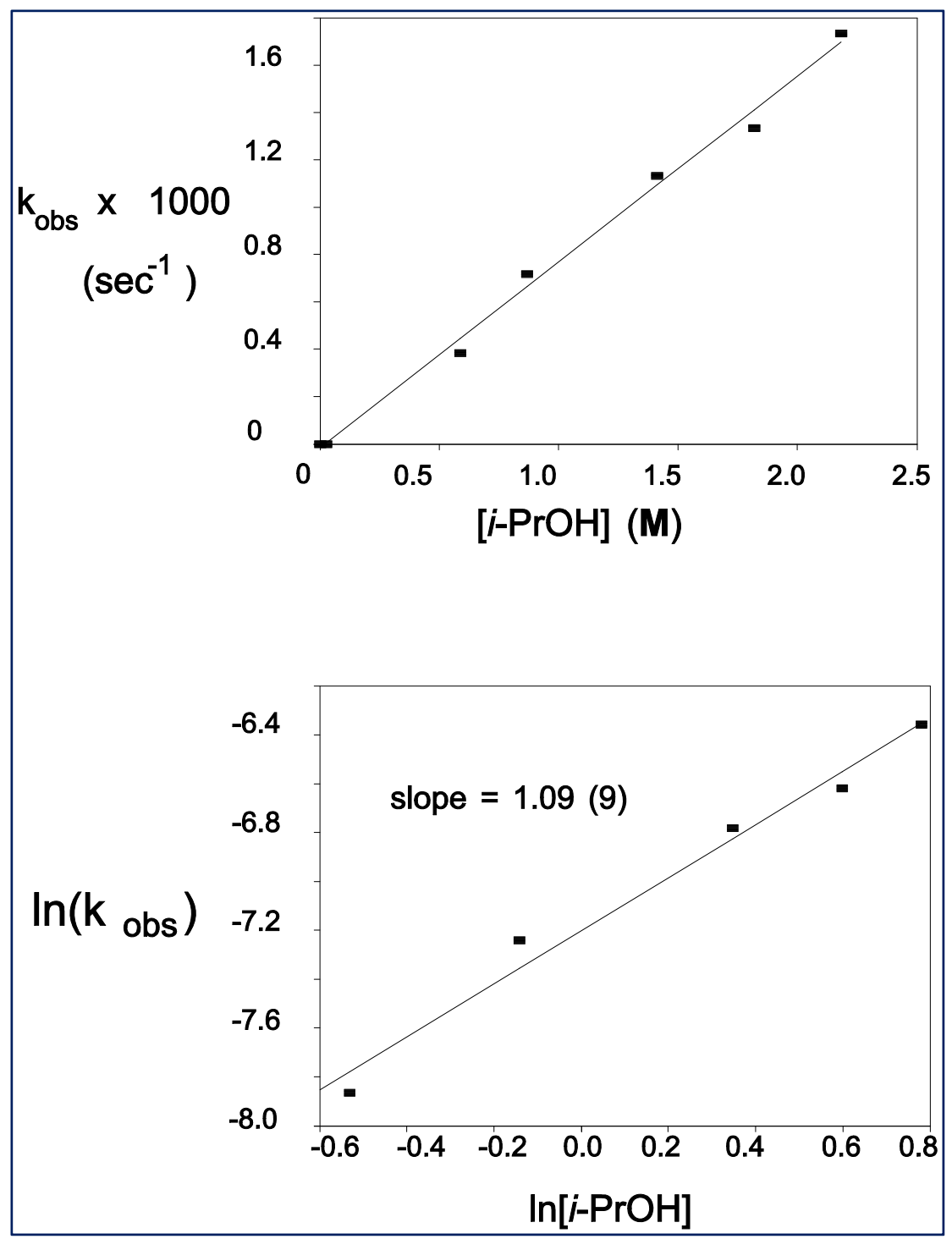

Figure 5. Effect of different concentrations of 2-propanol on the values of $k_{\text {obs. }}$ Measurements were carried out at $-19^{\circ} \mathrm{C}$ for the initial concentrations of $0.014 \mathrm{M}$ for complex 1 and varying concentration of 2-propanol in the range between 0.02 and $2.0 \mathrm{M}$, in dichloromethane solutions. 


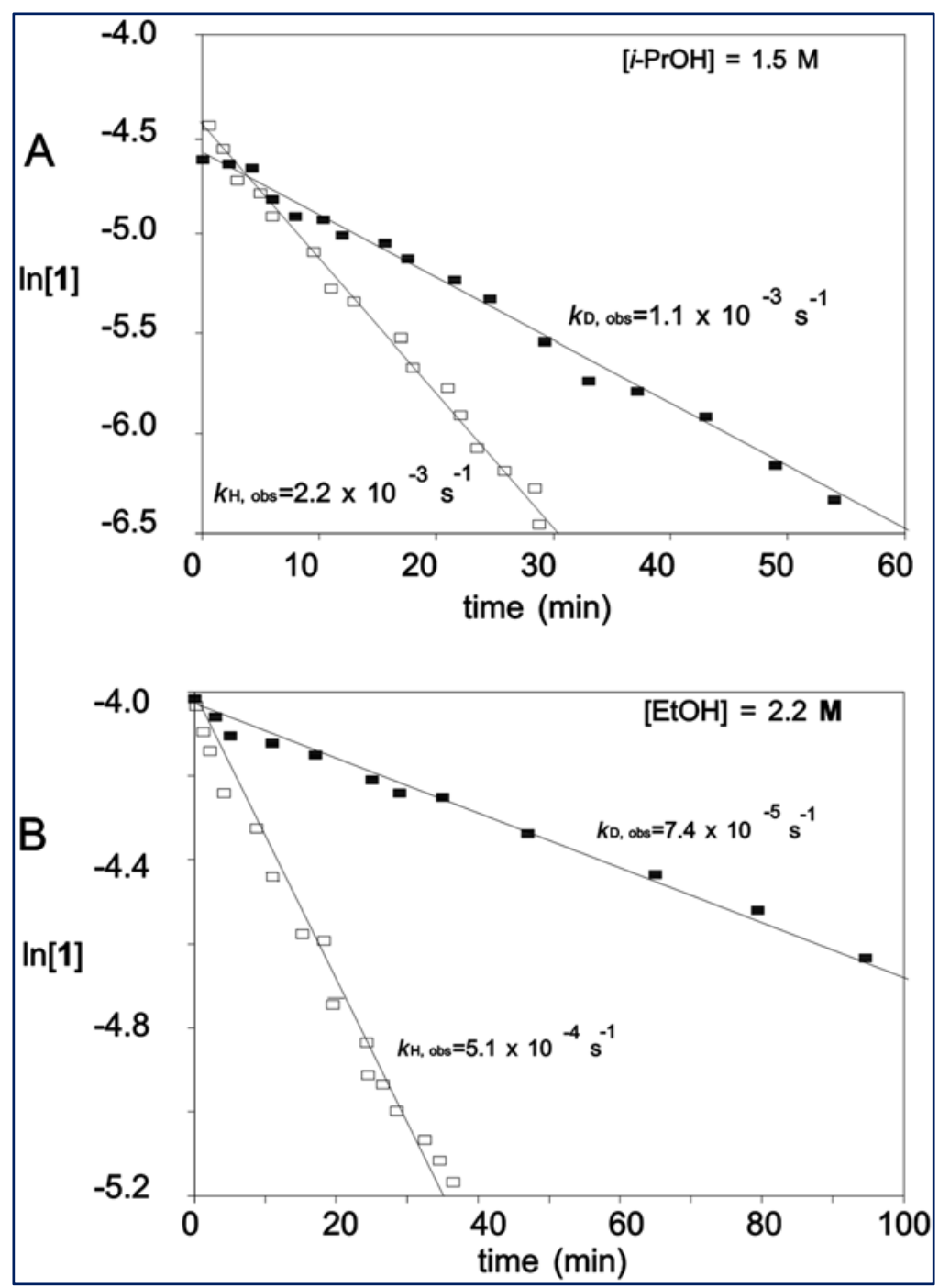

Figure 6. Pseudo-first order plots for the reaction of 1 with (A) $i$-PrOH and per-deutirated $i-$ PrOD in $\mathrm{CH}_{2} \mathrm{Cl}_{2}$ at $-11{ }^{\circ} \mathrm{C}$ (concentration of alcohol in both experiments is $1.5 \mathrm{M}$ ) and (B) EtOH and perdeutirated EtOD in $\mathrm{CH}_{2} \mathrm{Cl}_{2}$ at $-11{ }^{\circ} \mathrm{C}$ (concentration of alcohol in both experiments is 2.2 $\mathrm{M})$. 
Scheme 1

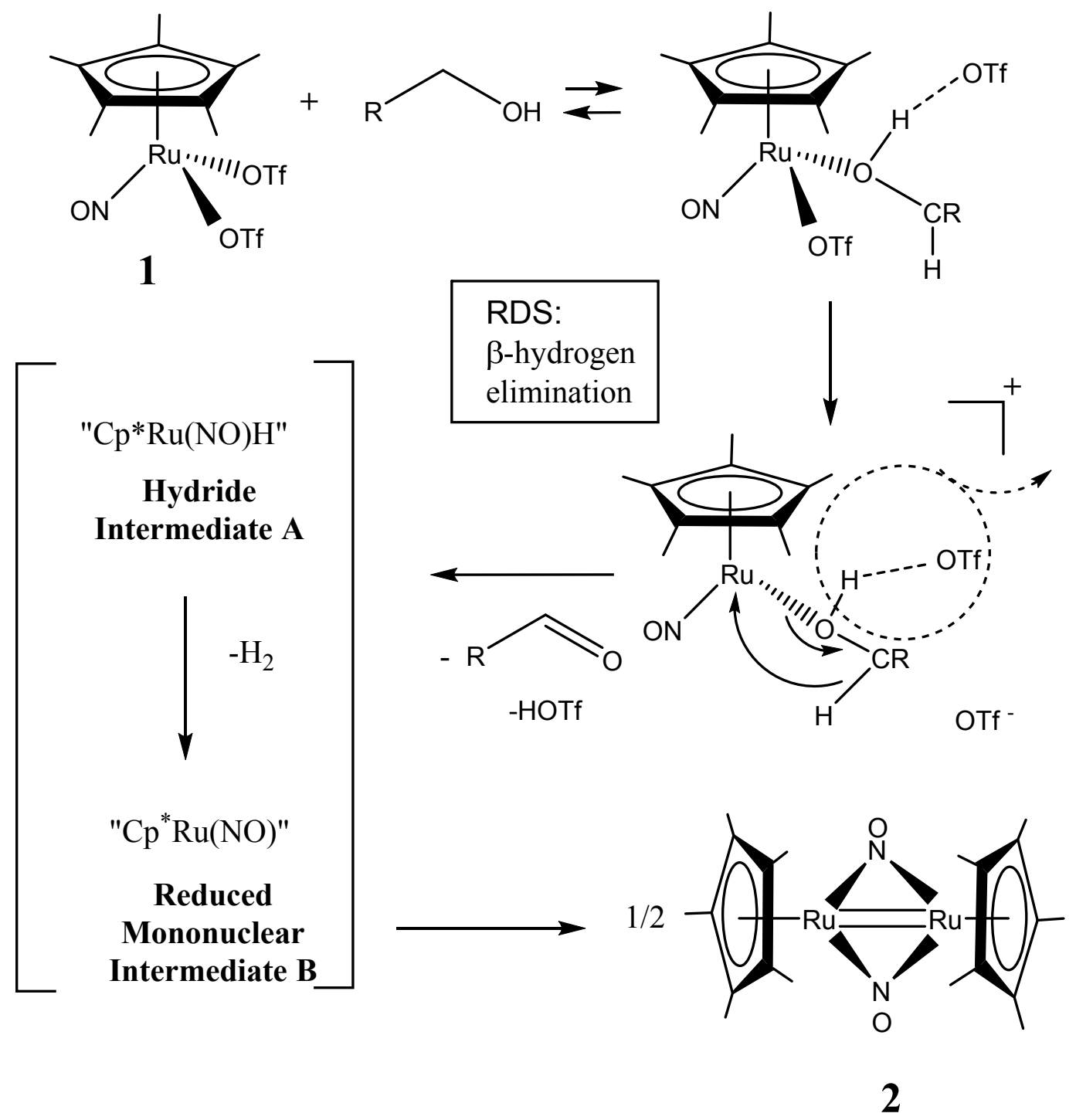


Table 1. Observed rate constants for the reaction of $\mathbf{1}$ with 2-propanol in $\mathrm{CH}_{\mathbf{2}} \mathrm{Cl}_{2}$.

\begin{tabular}{|c|c|c|c|c|}
\hline No. & {$[1], M \times 10^{-2}$} & {$[i-\mathrm{PrOH}], \mathrm{M}$} & $\mathrm{T},{ }^{\circ} \mathrm{C}$ & $k_{\mathbf{o b s}}{ }^{\mathbf{a}}, \mathrm{s}^{-1}$ \\
\hline 1 & 0.014 & 2.1 & -47 & $1.2 \times 10^{-4}$ \\
\hline 2 & 0.014 & 2.1 & -41 & $2.7 \times 10^{-4}$ \\
\hline 3 & 0.014 & 2.1 & -36 & $4.7 \times 10^{-4}$ \\
\hline 4 & 0.014 & 2.1 & -31 & $5.2 \times 10^{-4}$ \\
\hline 5 & 0.014 & 2.1 & -25 & $1.2 \times 10^{-3}$ \\
\hline 6 & 0.014 & 2.1 & -19 & $2.3 \times 10^{-3}$ \\
\hline 7 & 0.016 & 1.5 & -11 & $1.8 \times 10^{-3}$ \\
\hline 8 & 0.013 & 1.5 & -11 & $1.8 \times 10^{-3}$ \\
\hline 9 & 0.0065 & 1.5 & -11 & $2.0 \times 10^{-3}$ \\
\hline 10 & 0.009 & 1.5 & -11 & $1.9 \times 10^{-3}$ \\
\hline 11 & 0.014 & 0.02 & -19 & $0^{\mathbf{b}}$ \\
\hline 12 & 0.014 & 0.59 & -19 & $3.8 \times 10^{-4}$ \\
\hline 13 & 0.014 & 0.87 & -19 & $7.2 \times 10^{-4}$ \\
\hline 14 & 0.014 & 1.4 & -19 & $1.0 \times 10^{-3}$ \\
\hline 15 & 0.014 & 1.8 & -19 & $1.2 \times 10^{-3}$ \\
\hline 16 & 0.014 & 2.0 & -19 & $1.8 \times 10^{-3}$ \\
\hline
\end{tabular}

a The variation in the reproducibility of $k_{\mathbf{o b s}}$ is $15 \%$.

b No change in the integral value of 1 observed during $24 \mathrm{~h}$. 